\title{
Electrical and Structural Properties of Nickel Oxide - Containing Phosphate Glasses
}

\author{
R.M.M. Morsi, F.H. El-Batal ${ }^{*}$, I.M. Al-Anwar and M.M. \\ Morsi* \\ Physical Chemistry Dept. and ${ }^{*}$ Glass Research Dept., National \\ Research Centre, Cairo, Egypt .
}

\begin{abstract}
D HOSPHATE glasses containing $0.05-7.5 \mathrm{~g} \mathrm{NiO} / 100$ glass were prepared using sodium di-hydrogen phosphate. The prepared glasse were investigated using IR, a.c. conductivity, dielectric constant $\left(\varepsilon^{\prime}\right)$ and the dielectric loss $\left(\varepsilon^{\prime \prime}\right)$. IR spectra revealed that the $\mathrm{Ni}^{2+}$ ions are located near $\mathrm{P}=\mathrm{O}$. 9 Addition of $\mathrm{Na}_{2} \mathrm{O}$ causes a breakdown of the ring type with the formation of more non-bridging oxygens and depolymerization of the network. The conductivity of Ni-containing glasses is more than that of $\mathrm{Ni}$-free phosphate glass, and attain maximum value for glass containing $0.25 \mathrm{~g} \mathrm{NiO}$ per $100 \mathrm{~g}$ glass The relation between $\log \sigma$ and reciprocal of the temperature suggests that, the mechanism predominating in the high temperature region is ionic in nature, while it is electronic in origin in the low temperature region. Introducing $\mathrm{NiO}$ extends electronic conduction through hopping mechanism to the high temperature region particularly at high frequency. The dielectric constant $\varepsilon^{\prime}$ and the dielectric loss $\varepsilon^{\prime \prime}$ increase with increasing temperature, while a decrease in $\varepsilon^{\prime}$ with increasing frequency was observed.
\end{abstract}

Keywords: Phosphate glasses, Nickel oxide-containing glasses, Electrical conductivity, Dielectric constant and Dielectric loss.

Phosphate glasses are technologically important materials because they generally have higher thermal expansion coefficient, lower transition temperature and higher electric conductivity than silicate and borate glasses ${ }^{(1-3)}$. Phosphate glasses have very high transmission in the ultraviolet region which is a unique property when compared to that of silicate glasses. They are suitable materials for high power lasers because of low thermo-optical coefficient and large emission ${ }^{(4)}$.

Glasses containing transition metal ions are of great interest due to their uses in memory, photo-conducting devices cathode materials in dry batteries and magnetic materials ${ }^{(5-8)}$. Transition metal ions when present in oxide glasses form coordination complexes with the doubly charged oxygens, usually in 4-fold or 6fold coordination. The octahedral coordination is generally favored over the tetrahedral one, yet factors such as ionic radius, polarizability, glasses composition and Jahn-Teller distortion may modify the state of coordination in the glass ${ }^{(8)}$. In phosphate glasses transition metal ions exist in octahedral coordination ${ }^{(8-11)}$. 
Phosphate glasses are generally formed by $\mathrm{PO}_{4}$ tetrahedra connected by corners. Connection by three of four corners occurs in vitreous $\mathrm{P}_{2} \mathrm{O}_{5}$, leads to a three-dimensional network. The fourth corner is occupied by a terminal double bonded oxygen. Introduction of network modifiers, e.g. $\mathrm{Na}_{2} \mathrm{O}$, results in breaking $\mathrm{P}-\mathrm{O}-\mathrm{P}$ bonds with subsequent formation of terminal oxygens $\left(\mathrm{P}^{-} \mathrm{O}^{-}\right)$. Depending on the number of the bridging oxygen the phosphate structure can be described according to notations used by Lippma et al. ${ }^{(12)}$ as $\mathrm{Q}^{\circ}, \mathrm{Q}^{1}, \mathrm{Q}^{2} \& \mathrm{Q}^{3} \cdot \mathrm{Q}^{3}$ denotes a fully polymerized structure, while $\mathrm{Q}^{2}$ unit gives only a two-dimensional structure based on chains or rings. $\mathrm{Q}^{1}$ means two tetrahedra connected by a corner and $\mathrm{Q}^{0}$ means isolated tetrahedral ${ }^{(3,4)}$.

The optical properties of nickel-containing glasses have been extensively studied $^{(2,13)}$. The present work is concerning with giving more information about the electric properties and the structure characteristics of Ni-containing phosphate glasses.

\section{Experimental}

\section{Preparation of glass specimens}

Glasses were prepared using chemically pure sodium di-hydrogen phosphate as a starting basic material. $\mathrm{NiO}$ was introduced as finely powdered solid. $\mathrm{Na}_{2} \mathrm{O}$ or $\mathrm{P}_{2} \mathrm{O}_{5}$ were introduced in the glasses in the form of anhydrous sodium carbonate and ammonium dihydrogen phosphate, respectively, and their amounts were expressed as g per $100 \mathrm{~g}$ glass. Table 1 lists the compositions of the glasses studied. Glass batches were introduced in porcelain crucibles and heated first at $300^{\circ} \mathrm{C}$ to expel water and ammonia and then sintered at $850^{\circ} \mathrm{C}$ for $1 \mathrm{hr}$. The melts were rotated twice to ensure homogeneity. The homogenized melts were cast in preheated stainless steel molds in the required dimensions. The prepared samples were immediately transferred to a muffle furnace at $300{ }^{\circ} \mathrm{C} / \mathrm{hr}$, and then it was shut down to cool to room temperature.

\section{Infrared spectra measurements}

The $\mathrm{KBr}$ disc technique was used to measure the IR spectra of the prepared glass samples. The IR spectra were measured for the homogeneous discs at room temperature in the range 400-3000 $\mathrm{cm}^{-1}$ using Jasco FT/IR-300 E Spectrometer, Japan. Measurements were carried out immediately after preparing the desired discs.

\section{Electrical conductivity}

The a.c. method was applied to determine the electrical conductivity. A measuring circuit consisting of a sample holder (cell), high temperature furnace, variac and LCR HiTester (HIOKI, 3532-50) was used. Higher temperature was provided by increasing the input voltage of the variac transformer connected to

Egypt. J. Chem. 53, No. 1 (2010) 
the wire-wound resistance heater. The temperature was determined using a copper/constantine thermocouple in close proximity to the sample. The above procedure was followed after checking the validity of Ohm's law behavior, where the volt-current relationship was shown to be linear. The conductivity measurements were carried out over a temperature range of $25^{\circ} \mathrm{C}$ up to $190^{\circ} \mathrm{C}$. Moreover, the measurements were performed after sufficient time at each temperature, for establishing equilibrium values for conductivity. Conductivity $\sigma$ $\left(\Omega^{-1} \cdot \mathrm{cm}^{-1}\right)$ was obtained after recording the resistance $\left(\mathrm{R}_{\Omega}\right)$ by using the equations: $\sigma=1 / \rho, \rho=\mathrm{R}_{\Omega}$. $\mathrm{A}_{\mathrm{cm}} / \mathrm{d}$, where: $\mathrm{R}_{\Omega}=$ measured resistance $(\Omega \mathrm{cm})$, $\mathrm{A}_{\mathrm{cm}}=$ sample surface area $\left(\mathrm{cm}^{2}\right), \mathrm{d}=$ thickness of the sample $(\mathrm{cm})$.

TABLE 1. Nominal composition of the studied meta-phosphate glasses $\mathrm{Na}_{2} \mathrm{O}-\mathrm{P}_{2} \mathrm{O}_{5}$.

\begin{tabular}{|c|c|}
\hline Glass No. & Additions (g) per 100 g glass \\
\hline 0 & None \\
\hline 1 & $0.05 \mathrm{NiO}$ \\
\hline 2 & $0.25 \mathrm{NiO}$ \\
\hline 3 & $0.5 \mathrm{NiO}$ \\
\hline 4 & $7.5 \mathrm{NiO}$ \\
\hline 5 & $0.25 \mathrm{NiO}, 5 \mathrm{Na}_{2} \mathrm{O}$ \\
\hline 6 & $0.25 \mathrm{NiO}, 10 \mathrm{Na}_{2} \mathrm{O}$ \\
\hline
\end{tabular}

Dielectric constant ( $\left.\varepsilon^{\prime}\right)$ and dielectric loss ( $\left.\varepsilon^{\prime \prime}\right)$

The dielectric constant $\left(\varepsilon^{\prime}\right)$ and the dielectric loss $\left(\varepsilon^{\prime \prime}\right)$ were measured at frequency range from $0.1 \mathrm{KHz}$ to $5 \mathrm{MHz}$.. Measurements were carried out using LCR HiTester (HIOKI,3532-50). The temperature was determined using a copper/costantine thermocouple in close proximity to the sample. The following equations were used to obtain the dielectric constant $\left(\varepsilon^{\prime}\right)$ and dielectric loss $\left(\varepsilon^{\prime \prime}\right)$ : $\varepsilon^{\prime}=\mathrm{C} . \mathrm{d} / \varepsilon_{0} . \mathrm{A} ; \varepsilon^{\prime \prime}=\varepsilon^{\prime} . \mathrm{D}$, where: $\mathrm{C}=$ measured capacitance of the sample, $\mathrm{d}=$ thickness of the sample, $\varepsilon_{0}=$ permittivity of free space equals $8.85 \times 10^{-12}, \mathrm{~A}=$ sample surface area $\left(\mathrm{m}^{2}\right), \mathrm{D}=$ the power factor which is obtained directly from the instrument.

\section{Results and Discussion}

\section{Effect of $\mathrm{NiO}$ - content on the glass structure}

The IR spectra of glasses studied are characterized by four groups of bands found at 1200-1300, 800-1200, 700-800 and 400-600 $\mathrm{cm}^{-1}$ (Fig.1). The 
corresponding vibrations of structural groups giving rise to these bands and their assignments are listed in Table 2 . The band at $1302 \mathrm{~cm}^{-1}$ in the base glass originates from the $\mathrm{P}=\mathrm{O}$ double bonds vibrations in the $\mathrm{PO}_{2}{ }^{-1}$ terminal groups ${ }^{(3,4)}$. The position of this band slightly shifts from $1302 \mathrm{~cm}^{-1}$ to lower frequency as the $\mathrm{Ni}^{2+}$ ions concentration increases .It shifts to $1285 \mathrm{~cm}^{-1}$ in glass containing $7.5 \mathrm{~g}$ $\mathrm{NiO} / 100 \mathrm{~g}$ glass. This shift could be attributed to elongation of $\mathrm{P}=\mathrm{O}$ bond ${ }^{(4)}$. It is reasonable to assume that $\mathrm{Ni}^{2+}$ ions are located near $\mathrm{P}=\mathrm{O}$. It has been reported that IR absorption in the region $800-1200 \mathrm{~cm}^{-1}$ are sensitive for the different metaphosphate groups in the form of chain -, ring- terminal groups ${ }^{(3,14,15)}$. In this region the following bands were recorded in $\mathrm{Ni}-$ free glass (Glass no.0): 875,1000 and $1108\left(\mathrm{~cm}^{-1}\right)$. The absorption band at $875 \mathrm{~cm}^{-1}$ can be attributed to asymmetric stretching vibration of P-O-P groups linked with linear metaphosphate chain ${ }^{(16,17)}$. The band at $1000 \mathrm{~cm}^{-1}$ can be attributed to asymmetric stretching modes in phosphate tetrahedral linked with large metaphosphate rings ${ }^{(16,17)}$. This interpretation is in accordance with the assignment of the band at $935 \mathrm{~cm}^{-1}$ recorded in sodium phosphate glasses ${ }^{(3)}$. The band at $1108 \mathrm{~cm}^{-1}$ is also similar in position with that observed at $1130 \mathrm{~cm}^{-1}$ which shifted to $1098 \mathrm{~cm}^{-1}$ with changing glass composition ${ }^{(3)}$. This band has been assigned to asymmetric stretching of $\mathrm{PO}_{2}^{-}$groups, with the formation of terminal $\mathrm{PO}_{3}^{2-}$ groups.

The introduction of $\mathrm{NiO}$ in the base phosphate glass seems to have no effect on the bands located at $800-1200 \mathrm{~cm}^{-1}$. The bands at 762 and $722\left(\mathrm{~cm}^{-1}\right)$ are connected with symmetric stretching vibrations of P-O-P. This attribution is in accordance with that suggested by other authors ${ }^{(3,18)}$. The band at $762 \mathrm{~cm}^{-1}$ shows tendency to shift towards higher frequencies as $\mathrm{NiO}$ content was increased. A sharp band was observed at $480 \mathrm{~cm}^{-1}$ with a shoulder at $521 \mathrm{~cm}^{-1}$. The first band seems not sensitive to variation of $\mathrm{NiO}$ content. This band has been assigned to the bending variation of the O-P-O bond of $\left(\mathrm{PO}_{2}\right)^{n}$ chain groups ${ }^{(8)}$. The second band at $521 \mathrm{~cm}^{-1}$ shifts to higher frequencies with increasing $\mathrm{NiO}$ content. (Fig.1). This latter band can be attributed to bending variation of $\mathrm{P}=\mathrm{O}$, which is in consistence with the assignment given to similar band found at about $500 \mathrm{~cm}^{-1(8,16)}$. The shifts to higher frequencies mean a change in the strength of bond $\mathrm{P}=\mathrm{O}$ with increasing $\mathrm{NiO}$ content. This finding may confirm the presence of $\mathrm{Ni}^{2+}$ ions near by the $\mathrm{P}=\mathrm{O}$ bond. (Fig.2). The absorption bands shown in the region of frequencies higher than $1300 \mathrm{~cm}^{-1}$ were attributed to $\mathrm{H}_{2} \mathrm{O}$ and $\mathrm{P}-\mathrm{OH}$ vibrations ${ }^{(19)}$.

Egypt. J. Chem. 53, No. 1 (2010) 


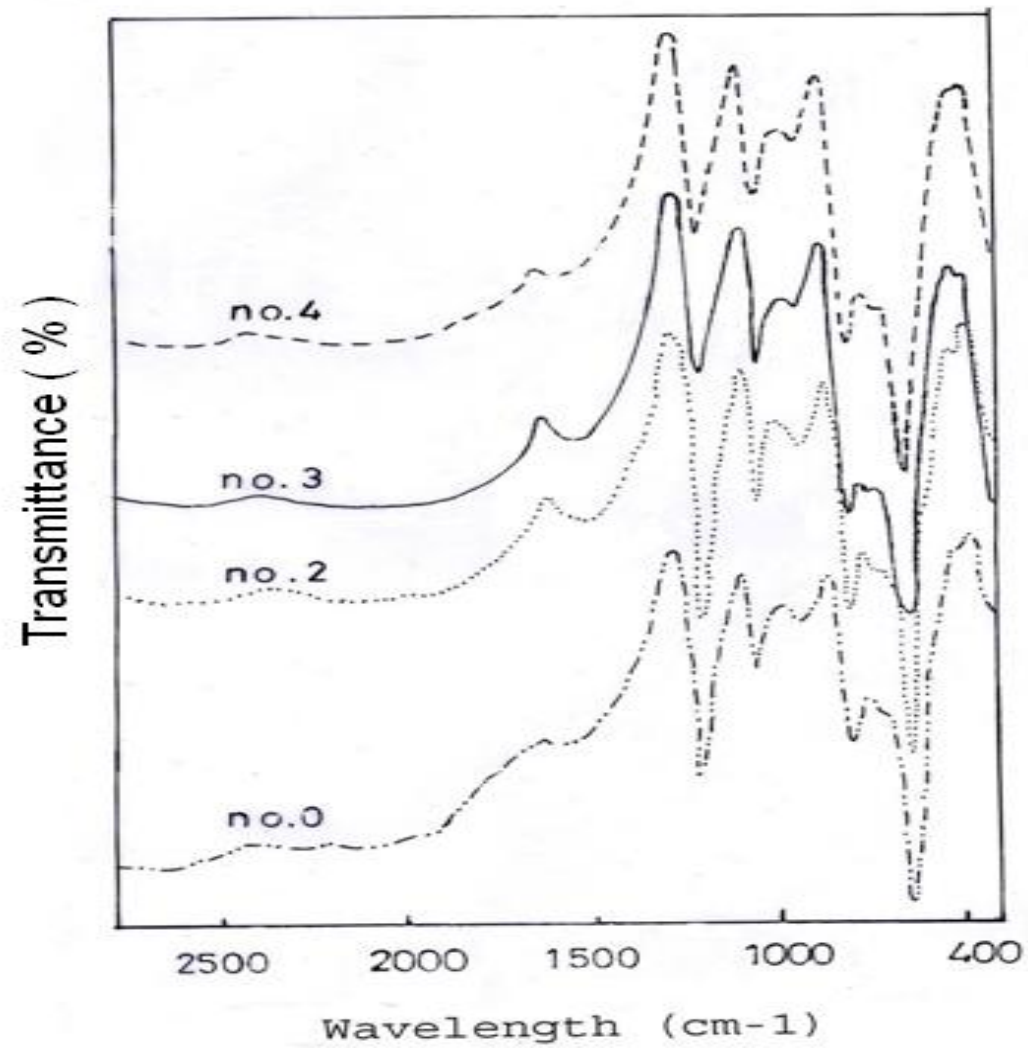

Fig. 1. IR spectra recorded in phosphate glasses with different $\mathrm{NiO}$ added per $100 \mathrm{~g}$ glass, No.1=0, $2=0.25,3=0.5$ and $4=7.5$.<smiles>COP(=O)(O)OP(=O)([O-])OP(=O)(O)OC</smiles>

Fig. 2. A possible structural group in Ni-containing phosphate glasses. 


\section{Effect of glass composition on the glass structure}

Figure 3 shows the effect of $\mathrm{Na}_{2} \mathrm{O}$ on the IR spectra when added to the phosphate Ni-containing glass. The positions of IR absorption bands $\left(\mathrm{cm}^{-1}\right)$ recorded in metaphosphate glasses containing $0.25 \mathrm{~g} \mathrm{NiO} / 100 \mathrm{~g}$ glass with additional amounts of $\mathrm{Na}_{2} \mathrm{O}$ per $100 \mathrm{~g}$ glass and possible assignments are listed in Table 2.

TABLE 2 .Position of absorption IR bands $\left(\mathrm{cm}^{-1}\right)$ for the studied glasses and possible

\begin{tabular}{|c|c|c|c|c|c|c|c|c|}
\hline $\begin{array}{c}\text { Glass } \\
\text { No. }\end{array}$ & $\left(\mathrm{PO}_{2}\right)^{-}$ & $\left(\mathrm{PO}_{3}\right)^{-}$ & \multicolumn{4}{|c|}{$\begin{array}{c}\text { P-O-P } \\
\text { bridges }\end{array}$} & $\begin{array}{c}\mathbf{P}=\mathbf{O} \\
\text { Bond- } \\
\text { ing }\end{array}$ & $\begin{array}{c}\text { O-P-O } \\
\text { Bond- } \\
\text { ing }\end{array}$ \\
\hline 0 & 1301 & 1108 & 1000 & $(875)^{1}$ & $(762)^{2}$ & $(722)^{3}$ & 521 & 480 \\
\hline 2 & $\begin{array}{l}1302 \\
1280\end{array}$ & 1092 & 1013 & $(875)^{1}$ & $(770)^{2}$ & $(732)^{3}$ & 525 & 480 \\
\hline 3 & 1284 & 1100 & 996 & $(883)^{1}$ & $(778)^{2}$ & $(732)^{3}$ & $\begin{array}{l}525 \\
529 \\
\end{array}$ & 485 \\
\hline 4 & 1285 & 1100 & 1004 & $(875)^{1}$ & $(770)^{2}$ & $(732)^{3}$ & 521 & 480 \\
\hline 5 & $\begin{array}{l}1388 \\
1294\end{array}$ & $\begin{array}{l}1152 \\
1101\end{array}$ & $\begin{array}{c}1020 \\
977\end{array}$ & $(875)^{1}$ & $(770)^{2}$ & $(705)^{3}$ & 533 & 489 \\
\hline 6 & $\begin{array}{l}1382 \\
1302\end{array}$ & $\begin{array}{l}1165 \\
1109\end{array}$ & $\begin{array}{c}1028 \\
980\end{array}$ & $(883)^{1}$ & $(762)^{2}$ & $(706)^{3}$ & 544 & 480 \\
\hline
\end{tabular}

asymmetric stretching. ${ }^{2}$ symmetric stretching. ${ }^{3}$ symmetric stretching of cyclic rings.

It is seen from Fig. 3 that, the addition of $\mathrm{Na}_{2} \mathrm{O}$ causes a drastic change in the structure of the metaphosphate glass as reflected by the changes taking place in the IR spectra. The P-O-P bridges with ring structures with band at $1012 \mathrm{~cm}^{-1}$ decreases with increasing $\mathrm{Na}_{2} \mathrm{O}$ content. This decrease was accompanied by an increase of the bands at the region $1280-1382 \mathrm{~cm}^{-1}$ due to $\mathrm{P}_{-} \mathrm{O}^{-}$in the terminal $\mathrm{PO}_{3}{ }^{-}$groups, and formation of P-O-P with chain structure (the bands at the region $700-900 \mathrm{~cm}^{-1}$ ). The addition of $\mathrm{Na}_{2} \mathrm{O}$ to phosphate glass causes a continuous breakdown of the ring type structure in the phosphate glass with the formation of more non-bridging oxygens and depolymerization of the network.

\section{a.c. Conductivity}

Figure 4 (a-e) shows the relation between $\log \sigma$ and reciprocal of temperature for different $\mathrm{Ni}$-doped and un-doped phosphate glasses measured at different frequencies $(1 \mathrm{KHz}$ to $5 \mathrm{MHz})$. The dependence of $\log \sigma$ on $1000 / \mathrm{T}$ is characterized by two temperature regions. The first is the lower temperature region where the conductivity increases slightly with temperature. The second region is the higher temperature region, where $\sigma$ increases with higher rate as the temperature increases. It can be seen from Fig. 4 (a-e) that, (for all glasses) the first region extends towards higher temperature as the measurement is carried out at higher frequencies. For low frequencies (particularly $1 \mathrm{KHz}$ and $100 \mathrm{KHz}$ ) the relation between $\log \sigma$ and reciprocal of the temperature obeys the well known Arrhenius equation: $\sigma=\sigma_{\mathrm{o}} e^{-\Delta \mathrm{E} / k T}$, where $\sigma_{\mathrm{o}}$ is the pre-exponential factor, $\Delta \mathrm{E}$ is Egypt. J. Chem. 53, No. 1 (2010) 
the activation energy, $\mathrm{k}$ is the Boltzmann constant and $\mathrm{T}$ is the absolute temperature. The activation energies of conduction at low and high temperature regions are calculated for those samples measured at $1 \mathrm{KHz}$ and listed in Table 3. It can be noticed that, the energy gap at low temperature region of samples is lower than that of high temperature region. This may be attributed to the different mechanisms in either region. The activation energy, $\Delta \mathrm{E}$, has values in the range $0.06-0.4 \mathrm{eV}$ and $1.25-1.6 \mathrm{eV}$ at the low and high temperature regions, respectively, for the free and $\mathrm{Ni}$-containing glasses. These data suggest that, the mechanism predominating in the high temperature region is ionic in nature, while it is electronic in origin in the low temperature region.

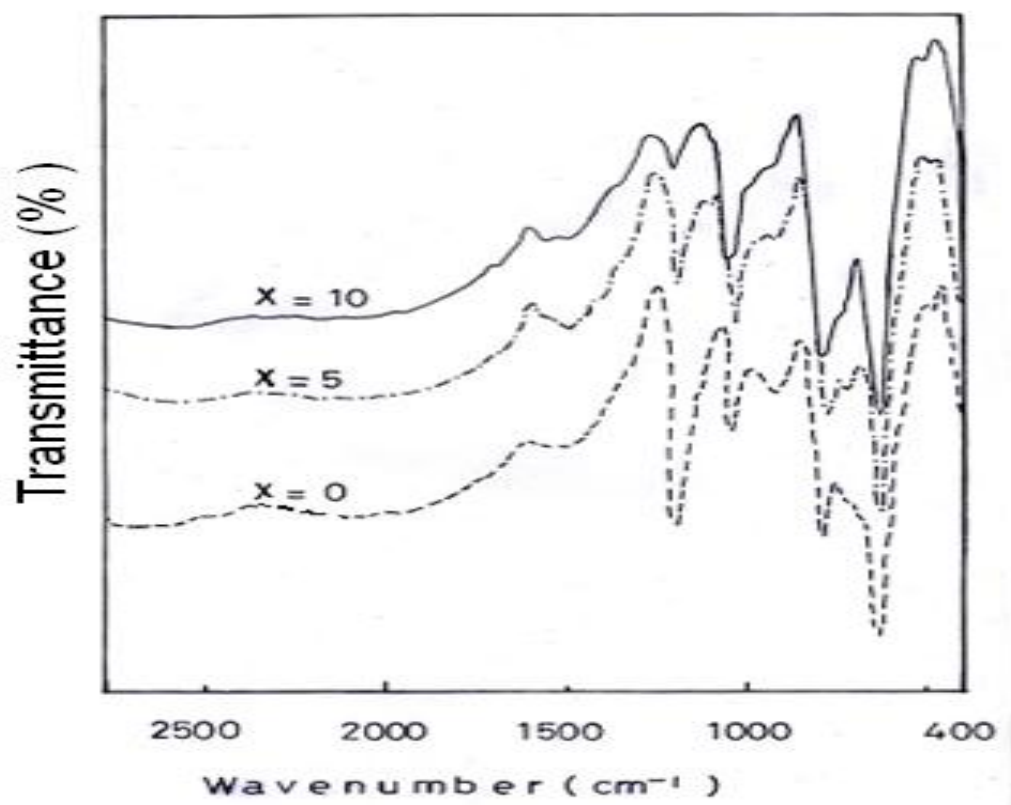

Fig. 3. IR spectra recorded in phosphate glasses with $0.25 \mathrm{NiO}$ and additional $\mathrm{x}$ gram $\mathrm{Na}_{2} \mathrm{O}$ ( added per $100 \mathrm{~g}$ glass).

TABLE 3. Activation energy $(\Delta E)$ of Ni-containing glasses measured at $1 \mathrm{KHz}$.

\begin{tabular}{|l|c|c|c|c|c|}
\hline Glass No. & $\mathbf{0}$ & $\mathbf{1}$ & $\mathbf{2}$ & $\mathbf{3}$ & $\mathbf{4}$ \\
\hline$\Delta \mathrm{E}(\mathrm{eV})$ at low temperature & 0.058 & 0.306 & 0.263 & 0.377 & 0.396 \\
\hline$\Delta \mathrm{E}(\mathrm{eV})$ at high temperature & 1.245 & 1.614 & 1.429 & 1.45 & 1.603 \\
\hline
\end{tabular}




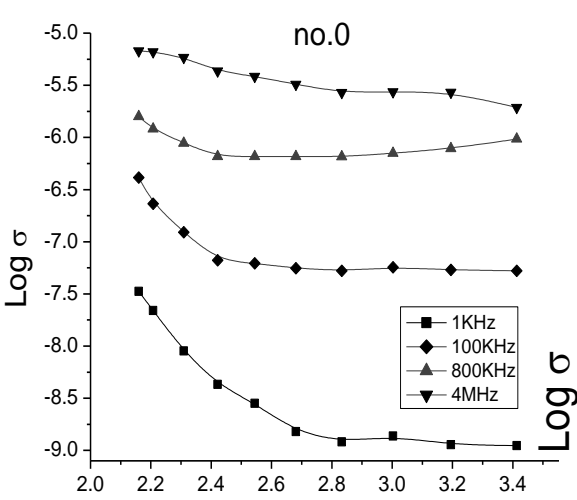

(a)

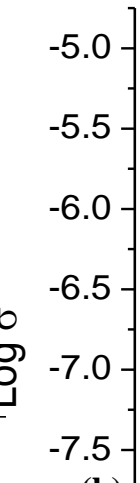

(b)

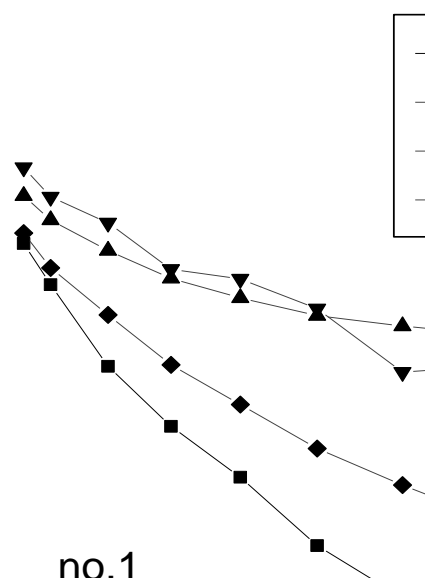

no. 1

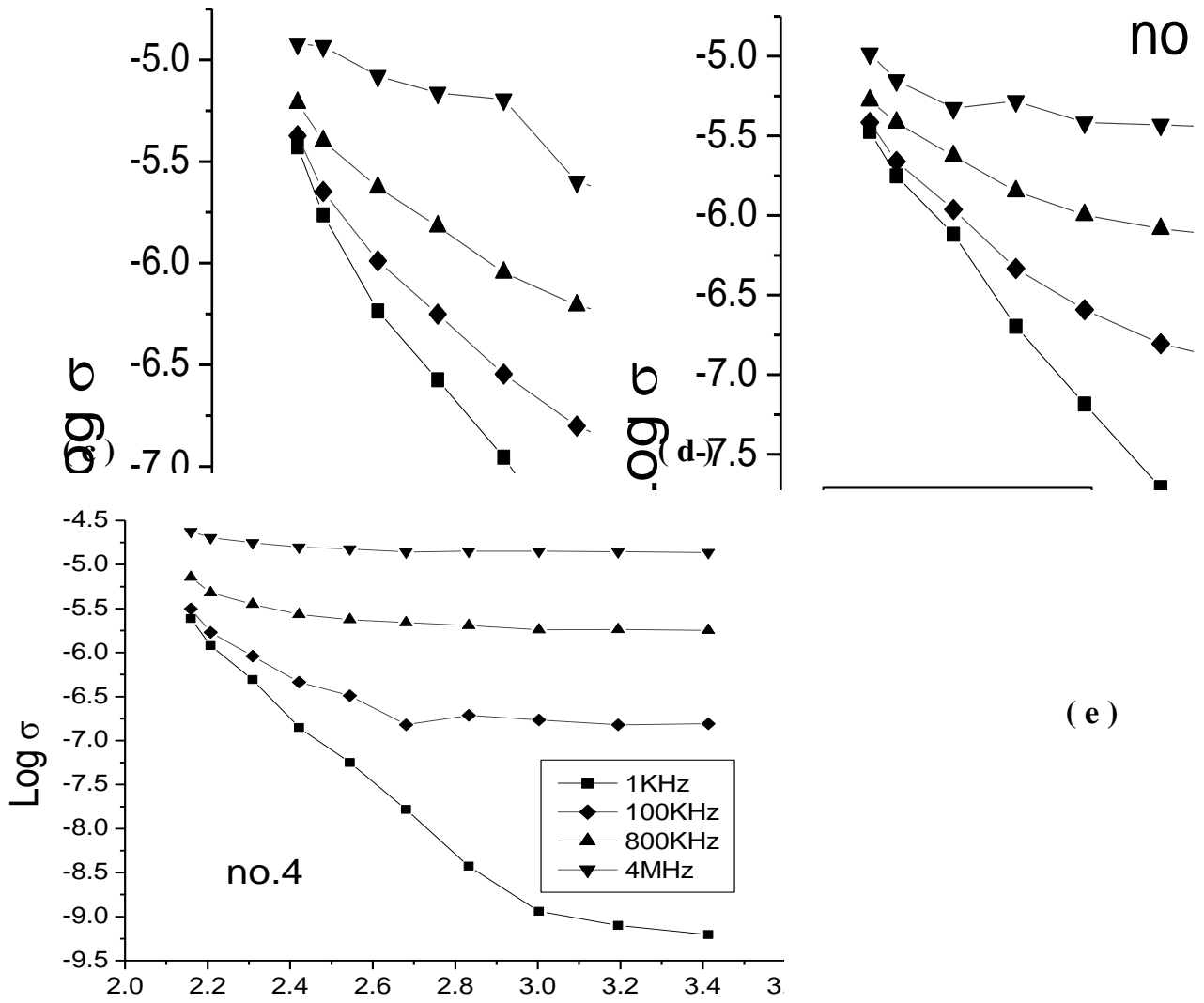

Fig. 4. $\mathrm{Log}$ conductivity versus reciprocal of temperature at $1 \mathrm{kHz}$ to $5 \mathrm{MHz}$ for glasses containing different $\mathrm{NiO}$ concentrations $(\mathrm{No} .0=$ zero, $1=0.05,2=0.25$, $3=0.5,4=7.5(\mathrm{~g} \mathrm{NiO}$ per $100 \mathrm{~g}$ glass $)$.

Egypt. J. Chem. 53, No. 1 (2010) 
It is worthy to notice (Fig. 4e) that, for high Ni-content glasses the log $\sigma$ becomes independent of temperature for high frequency measurements and with activation energy close to that of the Ni-free glass. This finding may indicate dominance of electronic conduction through hopping mechanism in such case.

The effect of $\mathrm{NiO}$ content on the conductivity was studied at different temperatures and frequencies. Figure 5 shows an example of such variation measured at $140^{\circ} \mathrm{C}$. It can be seen that, the first additions of $\mathrm{NiO}$ cause an abrupt increase in the conductivity up to maximum value for glass with $0.25 \mathrm{~g} \mathrm{NiO}$ per $100 \mathrm{~g}$ glass. Further increase in the $\mathrm{NiO}$ - content seems to hardly affect the conductivity due to blocking of interstitial vacancies in the glass structure.

Figure 6 shows the variation of $\log$ conductivity $\left(\Omega^{-1} . \mathrm{cm}^{-1}\right)$ with frequency at different temperatures for meta-phosphate glasses containing $0.25 \mathrm{~g} \mathrm{NiO} / 100 \mathrm{~g}$ glass. It can be noticed that, the conductivity increases as the frequency or temperature increases. The frequency dependence of ac conductivity of materials has been studied by several authors ${ }^{(20,21)}$. Increasing conductivity with increasing frequency at the same temperature has been attributed to the dielectric behavior of the sample ${ }^{(20)}$. The increased conductivity with increasing temperature is more pronounced at lower frequencies than at the higher ones.

\section{Dielectric properties}

Figures 7 and 8 show the temperature dependence of dielectric constant $\varepsilon$ and dielectric loss $\varepsilon^{\prime \prime}$, respectively, at spot frequency $1 \mathrm{KHz}$ for phosphate glasses containing different $\mathrm{NiO}$ concentrations. A transition temperature can be seen in the range between 140 and $160{ }^{\circ} \mathrm{C}$ above which $\varepsilon^{\prime}$ and $\varepsilon^{\prime \prime}$ abruptly increase. This observation has been attributed to the superposition of the two mechanisms, conduction and migration ${ }^{(20)}$. The effect of temperature below $100^{\circ} \mathrm{C}$ seems to be very small for $\varepsilon^{\prime \prime}$. In the case of $\varepsilon^{\prime}$ this effect is also very small for samples with high $\mathrm{NiO}$ content (No.3 and 4), yet samples with low concentrations (No.1 and 2) may show dispersion effect similar to NiO-free glass ( No. 0). The small effect of temperature below $100^{\circ} \mathrm{C}$ reflects that the migration mechanism plays a negligible role ${ }^{(20)}$. The observed increase of the dielectric constant (Fig.7) with increasing temperature is a typical behavior of the polar dielectrics in which the orientation of dipoles is facilitated with rising temperature and thereby the dielectric constant is increased. At low temperatures, the contribution of electronic and ionic components to the total polarizability will be small. As the temperature is increased the electronic and ionic polarizability sources start to increase ${ }^{(22)}$. 

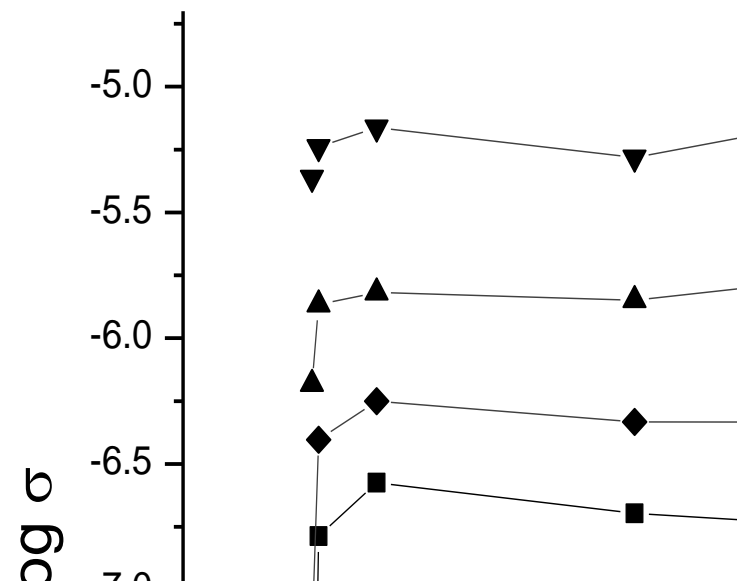

Fig. 5. Variation of conductivity with differenNiO - content (g per 100g glass) measured at $140^{\circ} \mathrm{C}$ for different frequencies.

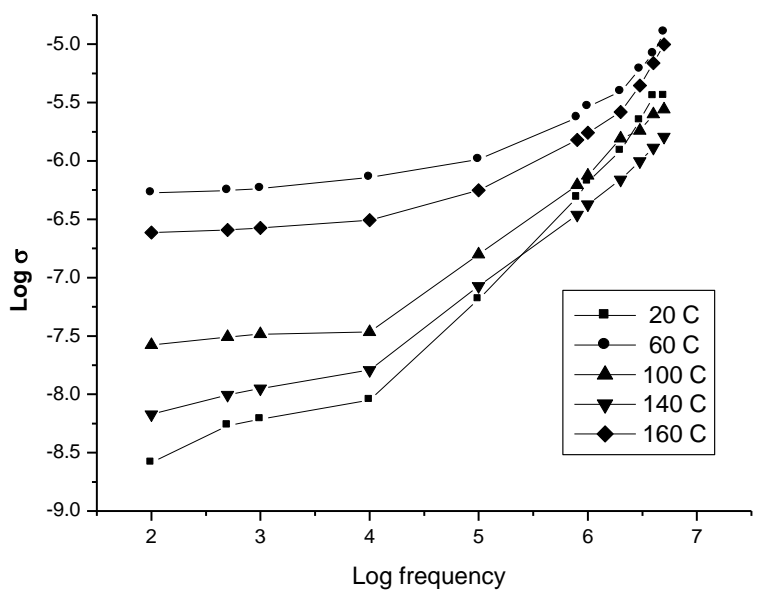

Fig. 6. Log conductivity vs. $\log$ frequency at different temperatures for glasses containing $0.25 \mathrm{~g} / 100 \mathrm{~g}$ glass batch .

Egypt. J. Chem. 53, No. 1 (2010) 


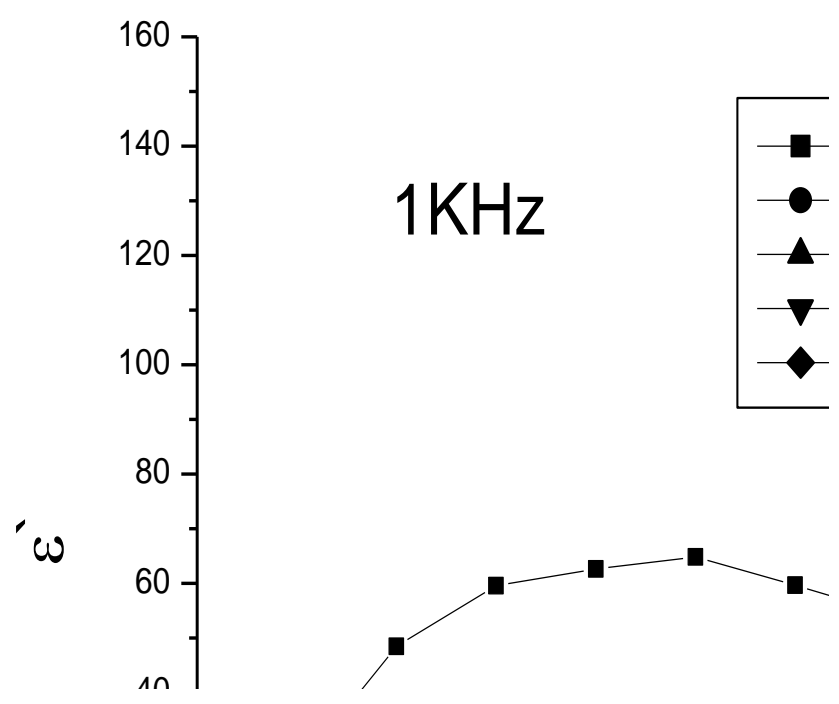

Fig. 7. Variation of dielectric constant with temperatures at $1 \mathrm{kHz}$ for glasses with different $\mathrm{NiO}$ concentrations ( $\mathrm{g} / 100 \mathrm{~g}$ glass).

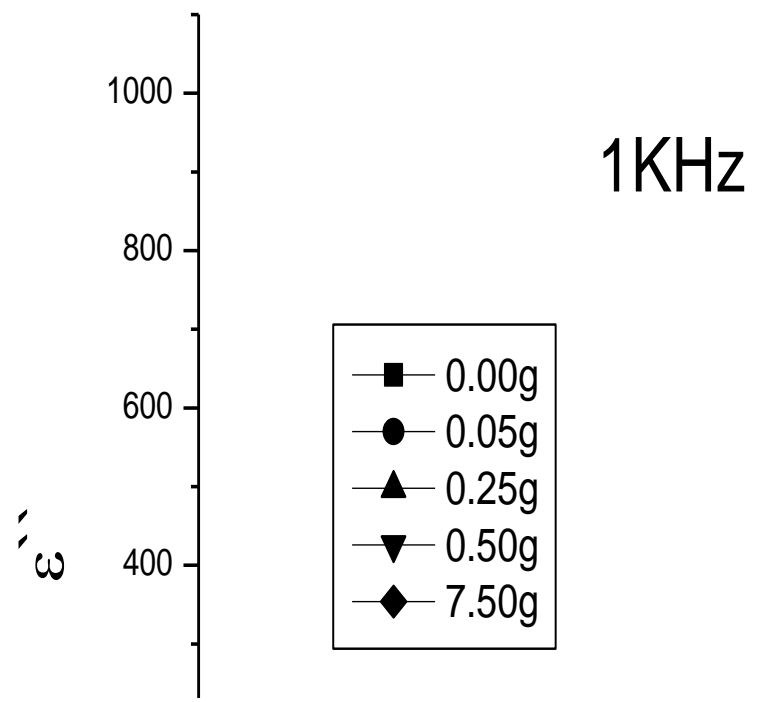

Fig. 8. Variation of dielectric loss $\varepsilon^{\prime \prime}$ with temperatures at $1 \mathrm{kHz}$ for glasses with different $\mathrm{NiO}$ concentrations (g /100g glass). 
Figure 9 shows the variation of dielectric constant with frequency for metaphosphate glasses containing $0.25 \mathrm{~g} \mathrm{NiO} / 100 \mathrm{~g}$ glass. It can be noticed that, the dielectric constant $\varepsilon^{\prime}$ decreases with increasing frequency. This may be due to the fact that as the frequency increases, the polarizability contribution from ionic and orientation sources decreases and finally disappears due to the inertia of the ions ${ }^{(22)}$. The noticed increase in the dielectric constant $\varepsilon^{\prime}$ at higher frequencies may indicate that the probability of new absorption may occur. The decrease in $\varepsilon^{\prime}$ with increasing frequency has also been attributed to the lag of the molecules behind the alternation of the electric field at higher frequency ${ }^{(23,24)}$.

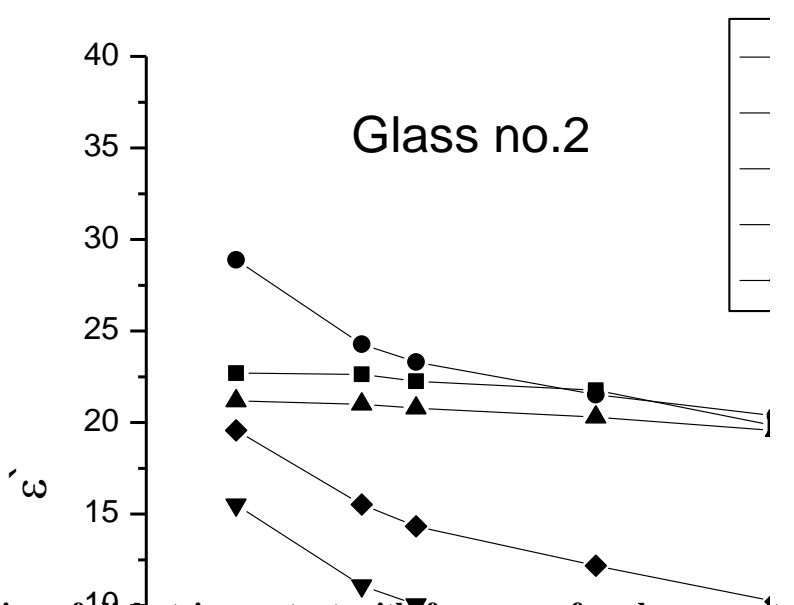

Fig. 9. Variation of 1 dietectric constant with 7 frequeney for glasses containing $0.25 \mathrm{~g}$ $\mathrm{NiO} / 100 \mathrm{~g}$ glass .

\section{Conclusions}

IR spectra revealed that the $\mathrm{Ni}^{2+}$ ions are located near $\mathrm{P}=\mathrm{O}$. 9Addition of $\mathrm{Na}_{2} \mathrm{O}$ to metaphosphate glass causes a breakdown of the ring type structure in the studied glasses with the formation of more non-bridging oxygens and depolymerization of the network.

The electric conductivity of Ni-containing glasses is more than that of free phosphate glass, and attained maximum value in presence of $0.25 \mathrm{~g} \mathrm{NiO}$ per $100 \mathrm{~g}$ glass. Further increase of $\mathrm{NiO}$ content hardly affects the conductivity.

The relation between $\log \sigma$ and reciprocal of the temperature obeys the well known Arrhenius equation. The data suggest that, the mechanism predominating in the high temperature region is ionic in nature, while it is electronic in origin in the low temperature region for all glasses and for low frequencies $(1 \mathrm{KHz}-$ $100 \mathrm{kHz}$ ) measurements. Introducing $\mathrm{NiO}$ extends the low temperature region to the high temperature one, indicating predominant of electronic conduction

Egypt. J. Chem. 53, No. 1 (2010) 
through hopping mechanism for high Ni-content (7.5g/100g glass) metaphosphate glasses particularly at high frequency $(4 \mathrm{MHz})$.

The dielectric constant $\varepsilon^{\prime}$ and the dielectric loss $\varepsilon^{\prime \prime}$ increase with increasing temperature. This behavior is typical to the polar dielectrics. A transition temperature can be seen in the range between 140 and $160{ }^{\circ} \mathrm{C}$ above which $\varepsilon$ and $\varepsilon^{\prime \prime}$ abruptly increase. This observation has been attributed to the superposition of the two mechanisms, conduction and migration.

The dielectric constant $\varepsilon^{\prime}$ decreases with increasing frequency due to decrease in the polarizability contribution from ionic and orientation sources and the lag of the molecules behind the alternation of the electric field at higher frequency.

\section{References}

1. Campbell, J.H. and Suratwala, T.J., Nd-doped phosphate glasses for highenergy/high-peak-power lasers. J. Non-Cryst. Solids, 263 \& 264, 318 (2000).

2. Sidek, H.A.A., Collier , I.T., Hampton , R.N. and Saunders, G.A., Electrical conductivity and dielectric constant of samarium phosphate glasses. Philos. Mag. B. 59, 221(1989).

3. Mostafa, Y.M. and El-Egili, K., Infrared spectra of sodium phosphate glasses. $J$. Non-Cryst. Solids, 240, 144 (1998).

4. Nocun, M., Structural studies of phosphate glasses with high ionic conductivity. $J$. Non- Cryst. Solids, 333, 90 (2004).

5. Hirashima, H., Watamate, Y. and Yohida, T., Switching of $\mathrm{TiO}_{2}-\mathrm{V}_{2} \mathrm{O}_{5}-\mathrm{P}_{2} \mathrm{O}_{5}$ glasses. J. Non-Cryst. Solids, 95/96, 825 (1987).

6. Sakuri, Y. and Yamaki, J., $\mathrm{V}_{2} \mathrm{O}_{5}-\mathrm{P}_{2} \mathrm{O}_{5}$ glasses as cathode for lithium secondary battery. J. Electrochem. Soc.132, 512 (1985).

7. Nakamura, S. and Ichinose, N., Study on amorphous ferrite $\mathrm{CaO}-\mathrm{Bi}_{2} \mathrm{O}_{3}-\mathrm{Fe}_{2} \mathrm{O}_{3}$ system. J. Non-Cryst.Solids, 95/96, 849 (1987).

8. El-Batal, F. H., Gamma ray interaction with copper-doped sodium phosphate glasses. J. Mater.Sci. 43 ,1070 (2008).

9. Sreekanth, R.P., Murali, C.A. and Rao, J.L., A study of electron paramagnetic resonance and optical absorption in calcium chromium phosphate glasses containing praseodymium. J. Alloys Compound, 281, 99 (1998).

10. El-Batal, F. H., Abo-Naf, S. M. and Ezzldin, F. M., Spectroscopic studies of gamma-irradiated transition metals-doped soda lime phosphate glass. Indian Journal of Pure \& Applied Physics, 43, 579 (2005). 
11. Marzouk, S.Y. and Marzouk, H.E., Ultraviolet-visible absorption of gammairradiated transition metal ions doped in sodium metaphosphate glasses. Nucl. Inst. Meth. Phys. Res. B 248, 90 (2006).

12. Lippmaa, E., Mägi, M., Samoson, A., Engelhardt, G. and Grimmer, A. R., Structural studies of silicates by solid-state high resolution 29Si NMR. J. Amer. Soc. Chem. 102, 4889 (1980).

13. Weyl, W. A., Colored Glasses. Sheffield, Soc.Glass Techn. London: Dawson'sof pall Mall (1959).

14. Kamitsos, E.I., Patis, A.P., Karakassides, M.A. and Chryssikos, G.D., Infrared reflectance spectra of lithium borate glasses. J. Non-Cryst. Solids, 126 , 52 (1990).

15. Kamitsos, E.I., Kapoutsis, J.A., Chryssikos, G.D., Hutchinson, J. M., Pappin, A. J., Ingram, M.D. and Duffy, J.A., Infrared study of $\mathrm{Ag}^{+}$-containing superionic glasses. Phys. Chem. Glasses, 36, 141 (1995).

16. Exarhos, G.J., In: Structure and Bonding in Non-Crystalline Solids, G.E. Walrafen and A. G. Revez (Ed.), Plenum, N.Y.(1986) .

17. Rulmont, A., Cahay, R., Liegeois-Duychaerts, M. and Tarte, P., Vibrational spectroscopy of phosphate: Some general correlations between structure and spectra. Eur. J. Solid State Inorganic Chem. 28, 207 (1991).

18. Hoppe, U., A structural model for phosphate glasses. J. Non-Cryst. Solids, 195,138 (1996).

19. Chahine, A., El-Tabirou, M., El-Benaissi, M., Hadded, M. and Pascal, J. L., Effect of $\mathrm{CuO}$ on the structure and properties of $(50-\mathrm{x} / 2) \mathrm{Na}_{2} \mathrm{O}-\mathrm{xCuO}-(50-\mathrm{x} / 2) \mathrm{P}_{2} \mathrm{O}_{5}$ glasses. Mater. Chem. Phys. 84, 341 (2004).

20. Tutky, G. and Dawy, M., Spectral and electrical properties of ternary $\left(\mathrm{TeO}_{2}-\mathrm{V}_{2} \mathrm{O}_{5^{-}}\right.$ $\mathrm{Sm}_{2} \mathrm{O}_{3}$ ) glasses. Materials Chemistry and Physics, 77, 48 (2002).

21. Yamazaki, Y. and Saton, M., High frequency conductivity in cobalt-iron ferrite, Jpn. J.Appl.Phys.12, 998 (1973).

22. El Hezzat, M., Et-tabirou, M., Montagne, L., Bekaert, E., Palavit, G., Mazzah, A. and Dhamelincourt, P., Structure and ac conductivity of sodium-lead-cadmium metaphosphate glasses. Materials Letters, 58, 60 (2004).

23. El-Anwar, I.M. and Saad, M., Silylation of cellulose IV: Electrical insulation properties. Bull. NRC. Egypt, 8, 151 (1983).

24. Nada, A.M.A. and Dawy, S.M., Dielectric properties of cellulose polyethylene glycol blends. Materials Chemistry and Physics, 84, 205 (2004). 


\section{الخصائص الكهربية والبنائية لزجاج الفوسفات المحتوى على اكسيا \\ النيكل}

محمدام مرسىى محمد مرسى ، فاطمة حاتم البطل * ، ابراهيم محمد الانور و مرسى

قسم الكيمياء الفيزيقية و * قسم بحوث الزجاج ـ المركز القومى للبحوث ـ القاهرة ـ

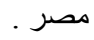

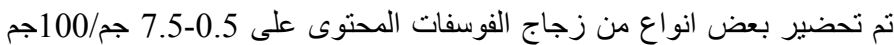

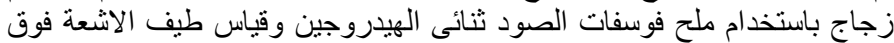

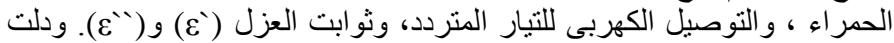

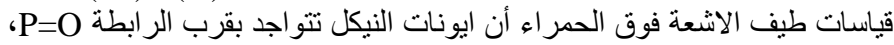

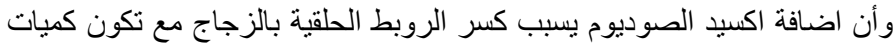

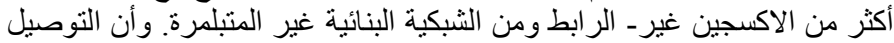

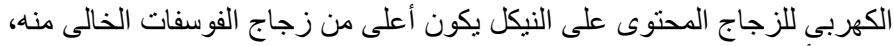

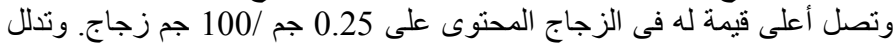

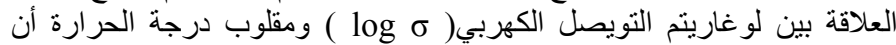

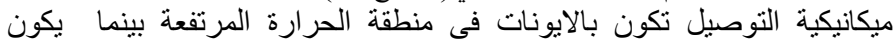

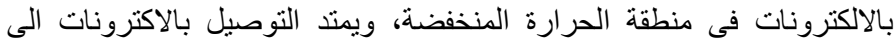

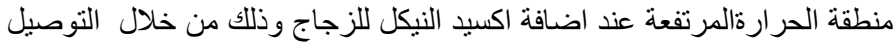

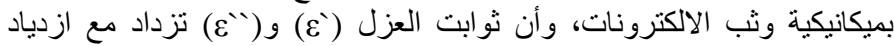

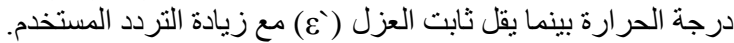

